University of Nebraska - Lincoln

DigitalCommons@University of Nebraska - Lincoln

1998

\title{
Methylenetetrahydrofolate reductase and methionine synthase: Biochemistry and molecular biology
}

\author{
R. G. Matthews \\ University of Michigan - Ann Arbor, rmatthew@umich.edu \\ Christal A. Sheppard \\ University of Nebraska-Lincoln, christalsheppard@unl.edu \\ C. Goulding \\ University of Michigan - Ann Arbor, celia.goulding@uci.edu
}

Follow this and additional works at: https://digitalcommons.unl.edu/lawfacpub

Part of the Legal Studies Commons

Matthews, R. G.; Sheppard, Christal A.; and Goulding, C., "Methylenetetrahydrofolate reductase and methionine synthase: Biochemistry and molecular biology" (1998). College of Law, Faculty Publications. 121.

https://digitalcommons.unl.edu/lawfacpub/121

This Article is brought to you for free and open access by the Law, College of at DigitalCommons@University of Nebraska - Lincoln. It has been accepted for inclusion in College of Law, Faculty Publications by an authorized administrator of DigitalCommons@University of Nebraska - Lincoln. 


\title{
Methylenetetrahydrofolate reductase and methionine synthase: Biochemistry and molecular biology
}

\author{
R. G. Matthews, C. Sheppard, and C. Goulding \\ Biophysics Research Division and Department of Biological Chemistry, University of Michigan, \\ 4028 Chemistry, 930 N. University Avenue, Ann Arbor, Michigan, 48109-1055, USA \\ Corresponding author - R. G. Matthews, Biophysics Research Division, University of Michigan, 4028 Chemistry, \\ 930 N. University Ave., Ann Arbor, Michigan 48109-1055, USA, e-mail: rmatthew@umich.edu, fax 313 764-3323
}

\begin{abstract}
Methylenetetrahydrofolate reductase and cobalamin-dependent methionine synthase catalyze the penultimate and ultimate steps in the biosynthesis of methionine in prokaryotes, and are required for the regeneration of the methyl group of methionine in mammals. Defects in either of these enzymes can lead to hyperhomocysteinemia. The sequences of the human methylenetetrahydrofolate reductase and methionine synthase are now known, and show clear homology with their bacterial analogues. Mutations in both enzymes that are known to occur in humans and to be associated with hyperhomocysteinemia affect residues that are conserved in the bacterial enzymes. Structure/function studies on the bacterial proteins, summarized in this review, are therefore relevant to the function of the human enzymes; in particular studies on the effects of bacterial mutations analogous to those causing hyperhomocysteinemia in human may shed light on the defects associated with these mutations.
\end{abstract}

Keywords: Hyperhomocysteinemia, Polymorphism, Mutations, Cobalamin, Vitamin $\mathrm{B}_{12}$

Abbreviations: AdoMet S-adenosylmethionine; AdoHcy adenosylhomocysteine

\section{Introduction}

With the growing interest in the clinical sequelae associated with homocysteinemia, attention has been directed towards studies of the enzymes responsible for the generation and consumption of homocysteine. As shown in Figure 1, methylenetetrahydrofolate reductase and methionine synthase are two such enzymes. Methylenetetrahydrofolate reductase catalyzes the reduction of methylenetetrahydrofolate to methyltetrahydrofolate. This is the only reaction generating methyltetrahydrofolate in the cell. Methionine synthase catalyzes a methyl transfer from methyltetrahydrofolate to homocysteine, generating methionine and tetrahydrofolate. In bacteria, the reaction catalyzed by methionine synthase is the terminal reaction in the de novo biosynthesis of methionine; in humans, for whom methionine is an essential amino acid, this reaction serves to regenerate the methyl group of methionine. As indicated in Figure 1, methionine is converted to adenosylmethionine (AdoMet), which serves as a methyl donor in numerous biosynthetic reactions. The product adenosylhomocysteine (AdoHcy) is then hydrolyzed to form adenosine and homocysteine. Homocysteine can be reconverted to methionine to provide another methyl group.

Homocysteine is a metabolite at a critical branch point in 1-carbon metabolism. If the cell is replete with AdoMet, and the ratio of AdoMet/AdoHcy is high, methylenetetrahydrofolate reductase is inhibited. Under these conditions the level of methyltetrahydrofolate in the cell is low, and homocysteine is degraded by conversion to cystathionine and thence to $\alpha$-ketobutyrate, ammonia, and cysteine. If the ratio of AdoMet/AdoHcy is low, signalling a need for synthesis of more AdoMet, methylenetetrahydrofolate reductase inhibition 


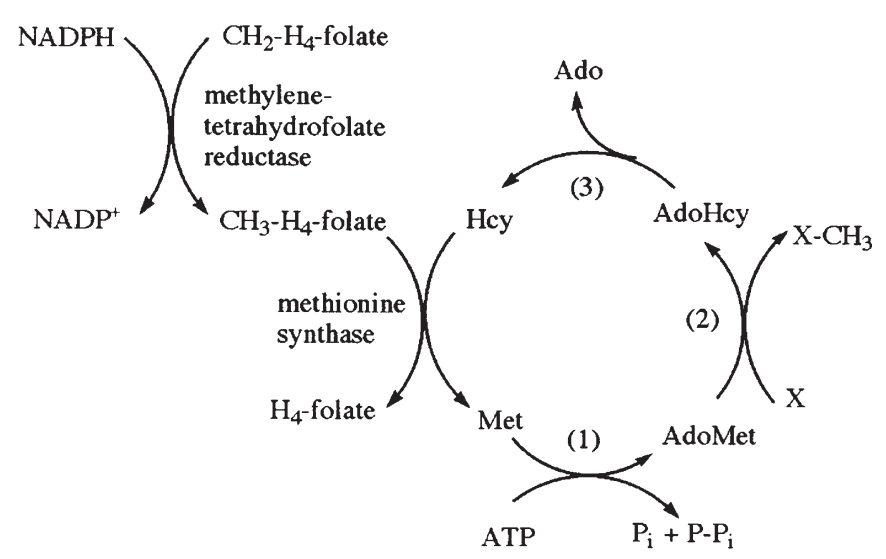

Figure 1. Pathways involved in the production of methyltetrahydrofolate and in the regeneration of homocysteine to form methionine. Enzymes (1) are the methionine adenosyltransferase isozymes, enzymes (2) are AdoMet-dependent methyltransferases, and enzyme (3) is S-adenosylhomocysteine hydrolase. $\mathrm{CH}_{2}-\mathrm{H}_{4}$ folate methylenetetrahydrofolate, $\mathrm{CH}_{3}-\mathrm{H}_{4}$ folate methyltetrahydrofolate, $\mathrm{H}_{4}$ folate tetrahydrofolate, $\mathrm{AdoHcy}$ adenosylhomocysteine, $\mathrm{Pi}$ phosphate anion, $P-P_{i}$ pyrophosphate anion.

is relieved, and methyltetrahydrofolate is produced to support the reaction of methionine synthase. Studies by Kutzbach and Stokstad [24] demonstrated that methylenetetrahydrofolate reductase acitvity is allosterically regulated by the AdoMet/ AdoHcy ratio, with AdoMet serving as an inhibitor, and AdoHcy competing with AdoMet for binding to the reductase but not acting as an inhibitor.

Defects in either methylenetetrahydrofolate reductase [21, $22,31]$ or methionine synthase $[35,41]$ can lead to hyperhomocysteinemia, as can deficiencies in $\beta$-cystathionase activity [2]. Severe defects, which lead to greatly elevated blood homocysteine levels, were the first to be identified, but recently we have realized that defects that lead to mild elevations in blood homocysteine levels are potential long-term risk factors [13, 37, 43]. Such mild defects may be associated with polymorphisms.

During the past 3 years, the nucleotide sequences for the human cDNAs specifying methylenetetrahydrofolate reductase [16] and methionine synthase [3, 25, 26] have been published. The availability of these sequences permits the identification of mutations that lead to impaired function of these enzymes, and hence to homocysteinemia. We are thus increasingly able to identify humans at risk for homocysteinemia and its sequelae. Extensive structural and functional studies of either the mammalian enzymes or their prokaryotic analogues have been performed, and thus studies can assist in understanding the defects associated with specific mutations, and can suggest strategies to ameliorate the symptoms caused by these mutations.

\section{Methylenetetrahydrofolate reductase}

Most of our knowledge about the structure and function of human methylenetetrahydrofolate reductase derives from studies of the closely related porcine enzyme. This enzyme was initially characterized by Kutzbach and Stokstad, and has subsequently been extensively studied in our laboratory. Kutzbach and Stokstad [24] partially purified the enzyme from porcine liver, and showed that it was allosterically regulated by AdoMet. The enzyme was subsequently purified to homogeneity [5], and shown to contain one equivalent of non-covalently bound FAD per enzyme subunit. The enzyme is a dimer of identical $77 \mathrm{kDa}$ subunits. Tryptic proteolysis of the native enzyme was shown to cleave each subunit into two fragments, an N-terminal $40 \mathrm{kDa}$ fragment and a C-terminal $37 \mathrm{kDa}$ fragment [30]. Tryptic cleavage results in loss of allosteric regulation of enzyme activity by AdoMet, but has no effect on the catalytic activity of the enzyme, suggesting that the protein may consist of separate catalytic and regulatory regions [30]. AdoMet was subsequently shown to bind to the Cterminal $37 \mathrm{kDa}$ fragment, implicating this fragment as the regulatory region [38].

The deduced amino acid sequence of the human enzyme provided further insight into the functional organization of methylenetetrahydrofolate reductase. The N-terminal region of the human protein showed extensive similarity with smaller proteins from enteric bacteria that catalyze the same reaction, namely the NAD $(\mathrm{P}) \mathrm{H}$-dependent reduction of methylenetetrahydrofolate. Since the activity of these enzymes is not allosterically regulated by AdoMet, there was a strong inference that the N-terminal region of the human enzyme is the catalytic region, and contains determinants for binding of FAD, NADPH, and methylenetetrahydrofolate. The C-terminal region of the human enzyme shows sequence similarities with the enzymes from yeast and from the roundworm Caenorhabditis elegans but this region is lacking in the bacterial methylenetetrahydrofolate reductases. The human enzyme contains an extremely hydrophilic region, Lys-Arg-Arg-Glu- Glu-Asp, that bridges the catalytic and regulatory regions; cleavage between Lys and Arg residues in this region would divide the protein into 40 and $34 \mathrm{kDa}$ fragments. The sequence of a peptide in the porcine enzyme that is labeled by irradiation of methylenetetrahydrofolate reductase in the presence of $\left[{ }^{3} \mathrm{H}-\right.$ methyl] AdoMet has been determined; a sequence similar to this peptide is located immediately downstream of the tryptic cleavage site [16].

Methylenetetrahydrofolate reductase from Escherichia coli had only previously been characterized in relatively impure preparations [23], and we have developed a method to purify this enzyme to homogeneity from an overexpressing strain. The purified enzyme is a flavoprotein, and contains non-covalently bound FAD as its cofactor. The enzymebound flavin is reduced by NADH, and much more slowly by $\mathrm{NADPH}$, and can in turn reduce methylenetetrahydrofolate to methyltetrahydrofolate.

Rozen and her collaborators [13, 16, 17] have conducted an extensive search for mutations in the human methylenetetrahydrofolate reductase gene, concentrating especially on mutations in the N-terminal catalytic region. Several mutations associated with severe deficiency in patients have been 
identified, two such point mutations are $\operatorname{Arg} 157 \mathrm{Gln}$, and Thr227Met. A polymorphism, Ala222Val, has been shown to be present in high frequency in humans; in a population of French Canadians Ala/Val heterozygotes are present at 51\% frequency, and $\mathrm{Val} / \mathrm{Val}$ homozymgotes at $12 \%$ frequency [13]. Humans who are homozygous for the polymorphism have reduced specific activity of methylenetetrahydrofolate reductase in fibroblast extracts, and demonstrate increased susceptibility to heat inactivation of enzyme activity (as assessed by measuring reductase activity after heating for $5 \mathrm{~min}$ at $46^{\circ} \mathrm{C}$ and comparing with the activity of controls) [13]. The Val/ Val genotype has subsequently been shown to be associated with increased risk for neural tube defects [40, 42], and possibly for the develoment of cardiovascular disease [11, 28], although not all studies have found significant correlations [6]. Each of the mutated residues, Arg157, Thr227, and Ala222, is conserved in the bacterial, yeast, and roundworm sequences of methylenetetrahydrofolate reductase.

Because the human methylenetetrahydrofolate reductase has not yet successfully been overexpressed and purified, we have constructed a homologous mutation to Ala222Val in the methylenetetrahydrofolate reductase from E. coli, Ala177Val. This mutation leads to diminished expression of methylenetetrahydrofolate reductase in an overexpressing strain, and the enzyme activity is rapidly lost during purification. We have successfully purified the mutant bacterial enzyme to homogeneity by introducing a histidine tag at the C-terminus of the protein and purifying the enzyme on nickel Sepharose. Our present studies suggest that the Ala177Val bacterial enzyme is indeed thermolabile, and that it readily loses its flavin cofactor on dilution of the protein.

The reduced specific activity of methylenetetrahydrofolate reductase in humans with the thermolabile mutation [11], and the resultant elevation in homocysteine in patients with low folate status [19], may similarly reflect the presence of inactive apo-enzyme in the cells of these individuals.

\section{Methionine synthase}

Cobalamin-dependent methionine synthase from E. coli was initially characterized in the laboratories of Wood, Weissbach, and Huennekens (reviewed in [29]). These studies established the participation of the cobalamin $\left(\mathrm{B}_{12}\right)$ cofactor in the methyl transfer from methyltetrahydrofolate to homocysteine, and defined the requirements for catalytic turnover. As shown in Figure 2, the cofactor cycles in catalysis between the methylcobalamin form and the cob(I)alamin form. Cob(I)alamin is a strong reductant, and is occasionally oxidized during catalytic turnover in the presence of oxygen to produce the inactive cob(II) alamin form of the enzyme. Return of this form of the enzyme to the catalytic cycle requires a reductive methylation, in which the methyl group is provided by AdoMet [27]; in E. coli, reduced flavodoxin serves as the electron donor [14]. Thus catalytic turnover in the presence of oxygen requires homocysteine and methyltetrahydrofolate, AdoMet and a reducing system.

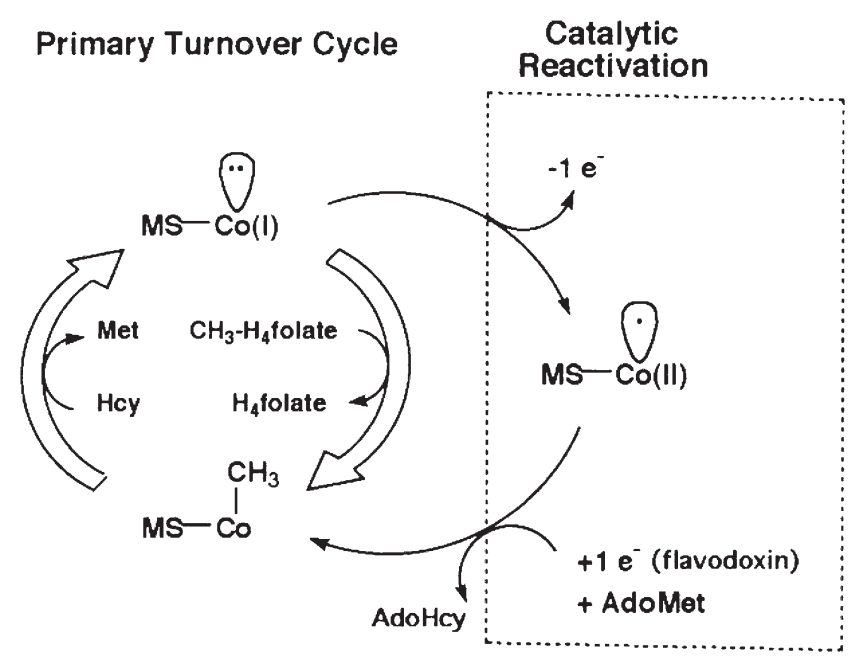

Figure 2. Chemistry of the methionine synthase $(M S)$ reaction. In normal catalysis the $\mathrm{B}_{12}$ prosthetic group cycles a between cob(I)ala$\min (\mathrm{CO}(\mathrm{I}))$ and methylcobalamin $\left(\mathrm{Co}-\mathrm{CH}_{3}\right)$. Homocysteine demethylates methylcobalamin to generate methionine and $\operatorname{cob}(\mathrm{I})$ alamin and the latter is remethylated by methyltetrahydrofolate $\left(\mathrm{CH}_{3}-\mathrm{H}_{4}\right.$ folate $)$ with formation of tetrahydrofolate. Occasionally, the cob(I)alamin form of the enzyme becomes oxidized to the inactive cob(II)alamin form of the enzyme. Return of this form of the enzyme to the catalytic cycle requires a reductive methylation. In $E$. coli, the electron is supplied by reduced flavodoxin; the electron donor in mammals has not yet been identified. AdoMet supplies the methyl group for reductive activation.

The E. coli methionine synthase was first cloned, overexpressed and sequenced in 1989-1990 [1, 32, 33]. As noted above, the sequence of the human methionine synthase has been simultaneously determined in three laboratories this year $[3,25,26]$. The human enzyme shows $58 \%$ identity with methionine synthase from E. coli [3]. These two sequences, as well as sequences from the roundworm Caenorhabditis elegans [39], and the prokaryotes Hemophilus influenzae [12], Mycobacterium leprae [36], and Synechocystis sp. strain PCC6803 [20], are aligned in Figure 3. Given the high degree of conservation of amino acid residues throughout the proteins, the enzymes from these organisms are likely to have very similar properties and structures. Thus the large body of information available for the $E$. coli enzyme is likely to be relevant to the human enzyme.

The porcine methionine synthase has been purified to homogeneity [4] and shown to be similar in size and properties to the enzyme from $E$. coli. The one respect in which the mammalian enzymes clearly differ from the bacterial proteins is in the nature of the biological reducing system. Mammals lack flavodoxin, necessary for reductive reactivation in $E$. coli; the proteins responsible for reductive activation in mammals have not yet been identified.

Our recent studies on the bacterial enzyme have shown it to be a modular protein, consisting of four regions that are designated in Figure 3. The N-terminal module (residues 1-353 in the E. coli sequence) is responsible for binding and 


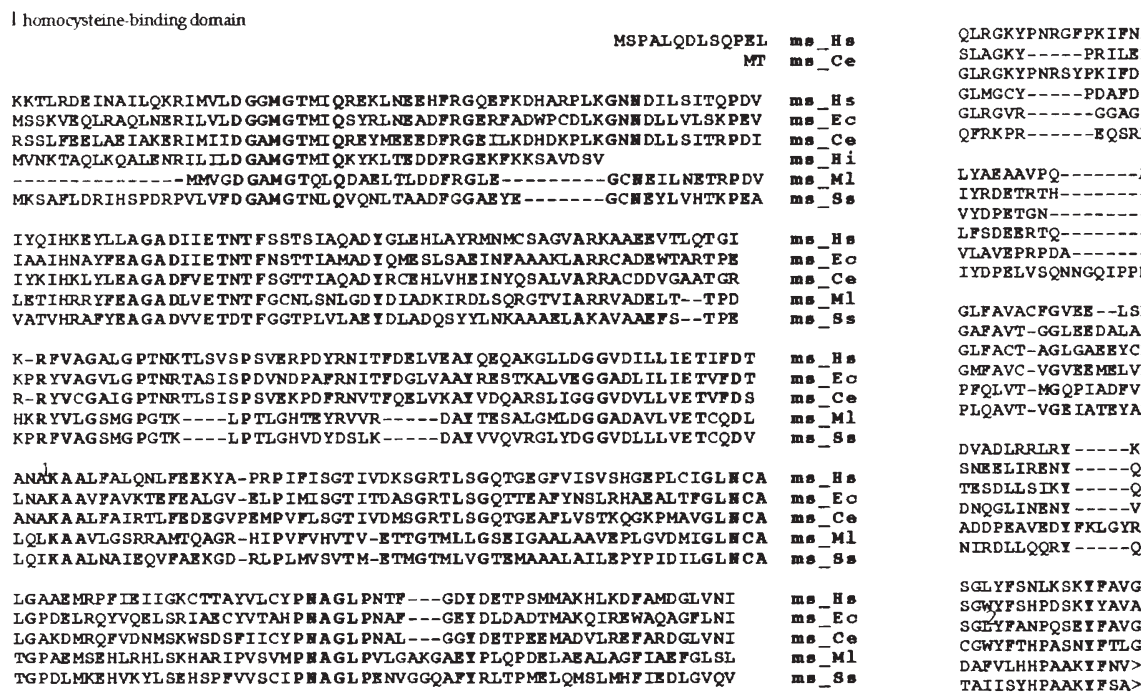

ms_B

msice

ms_Ml

$\mathrm{ms}-\mathrm{Hs}$

$\min -\mathrm{Ce}$

ms $-\mathrm{Ml}$

$\mathrm{ms}-\mathrm{HB}$

ms-ce

ms-M1

$m s-H s$

ms-Ce

$m s-8 s$

TAIISYHPAAKY $\mathrm{TSA}$

ms

$\mathrm{ms}$ म $\mathrm{s}$
$\mathrm{ms}-\mathrm{Eo}$

ms_Ce

$m s-8 s$

ms

$\mathrm{ms} C \mathrm{Ce}$

ms- 8 s

$m s$ H B :

ms_co

$\mathrm{ms}-\mathrm{M} 1$

ms

ms $-E 0$

mis

ms_ss

ms B Bs

ms_Eo

$m B^{-}$MI

ms_Bs

ms-Eo

$\mathrm{ms}_{\mathrm{ms}}-\mathrm{Hi}$

ms

$\mathrm{mm}-\mathrm{HB}$
$\mathrm{mB}-\mathrm{EO}$

ms - ce
Figure 3. Aligment of the methionine synthase sequence from Homo sapiens $[3,25,26]$ with the sequence from the E. coli metH gene $[1,10,33]$, and homologous sequences from the roundworm Caenorhabditis elegans [39], and the prokaryotes Hemophilus influenzae [12]. Mycobacterium leprae [36], and Synechocystis sp. strain PCC6803 [20]. Identical residues are shown in bold. The Hemophilus sequence appears to lack most of the N-terminal portion of the sequence of the other genes, perhaps because it was obtained by shotgun cloning of the entire genome.

activation of homocysteine (Goulding and Matthews, unpublished data) and shows sequence similarity with human betaine-homocysteine methyltransferase [15]. The next module, comprising residues $354-649$, is involved in the binding and activation of methyltetrahydrofolate. This module shows sequence similarities with a methyltransferase from Clostridium thermoaceticum that catalyzes methyl transfer from methyltetrahydrofolate to a separate corrinoid iron/sulfur protein [34]. The third module of the bacterial enzyme, comprising residues 650-896, contains the determinants for binding the cobalamin cofactor $[1,8,34]$, and presents the cofactor to the other three modules. A high resolution X-ray structure of this module has been determined [8]. The fourth and last module, containing residues 897-1227, binds AdoMet and is required for reductive activation of methionine synthase [9]. An X-ray structure of this module, with AdoMet bound, has recently been determined [7].

Thus, as mutations and polymorphisms of human methionine synthase are identified, we may be able to guess at their probable phenotypes from their location in the sequence. One such mutation, Pro1137Leu, is associated with severe disease in humans [18]. This mutation is located in the activation module of methionine synthase, adjacent the bound AdoMet. This mutation has a very interesting phenotype; it is active when assayed using a chemical reducing system, but shows very low activity when assayed with the biological reducing system [18]. Thus this mutation in the activation domain of methionine synthase appears to have altered the interaction of human methionine synthase with its biological reducing agent. 
Analysis of other mutations and polymorphisms may not only tell us whether methionine synthase mutations are independent risk factors for neural-tube defects and/or cardiovascular disease, but may also tell us much about the role of the methionine synthase protein in catalyzing methyl transfer.

Acknowledgments - Work in the authors' laboratory has been supported by a grant, GM24 908, from the National Institute of General Medical Sciences. Christal Sheppard has been supported in part by Minority Fellowship Award 1F31 DK09421 from the National Institutes of Health, and by a Rackham Merit Fellowship from the University of Michigan.

\section{References}

1. Banerjee RV, Johnston NL, Sobeski JK, Datta P, Matthews RG (1989) Cloning and sequence analysis of the Escherichia coli metH gene encoding cobalamin-dependent methionine synthase and isolation of a tryptic fragment containing the cobalamin- binding domain. J Biol Chem 264: 13888-13895

2. Carson NAJ, Neill DW (1962) Metabolic abnormalities detected in a survey of mentally backward individuals in Northern Ireland. Arch Dis Child 37: 505-513

3. Chen LH, Liu M-L, Hwang H-Y, Chen L-S, Korenberg J, Shane B (1997) Human methionine synthase: cDNA cloning, gene localization and expression. J Biol Chem 272: 3628-3634

4. Chen Z, Crippen K, Gulati S, Banerjee R (1994) Purification and kinetic mechanism of a mammalian methionine synthase from pig liver. J Biol Chem 269: 27 193-27197

5. Daubner SC, Matthews RG (1982) Purification and properties of methylenetetrahydrofolate reductase from pig liver. In: Massey V, Williams CH (eds) Flavins and flavoproteins. Elsevier, New York, pp 165-172

6. De Franchis R, Sebastio G, Mandato C, Andria G, Mastroiacovo P (1995) Spina bifida, 677T $\rightarrow$ C mutation, and role of folate. Lancet 346: 1703

7. Dixon MM, Huang S, Matthews RG, Ludwig M (1996) The structure of the $\mathrm{C}$-terminal domian of methionine synthase: presenting $\mathrm{S}$ adenosylmethionine for reductive methylation of B12. Structure 4: $1263-1275$

8. Drennan CL, Huang S, Drummond JT, Matthews RG, Ludwig ML (1994) How a protein binds $\mathrm{B}_{12}$ : A $3.0 \AA \mathrm{x}$-ray structure of the $\mathrm{B}_{12}$ binding domains of methionine synthase. Science 266: 1669-1674

9.Drummond JT, Huang S, Blumenthal RM, Matthews RG (1993) Assignment of enzymatic function to specific protein regions of cobalamin-dependent methionine synthase from Escherichia coli. Biochemistry 32: 9290-9295

10.Drummond JT, Orgorzalek Loo RR, Matthews RG (1993) Electrospray mass spectrometric analysis of the domains of a large enzyme: observation of the occupied cobalamin-binding domain and redefinition of the carboxyl terminus of methionine synthase. Biochemistry 32: 9282-9289

11. Engbertsen AMT, Franken DG, Boers GHJ, Stevens EMB, Trijbels FJM, Blom HJ (1995) Thermolabile 5,10-methylenetetrahydrofolate reductase as a cause of mild hyperhomocysteinemia. Am J Hum Genet 56: $142-150$
12. Fleischmann RD, Adams MD, White O, Clayton RA, Kirkness EF, Kerlavage AR, Bult CJ, Tomb J-F, Dougherty BA, Merrick JM, al. e (1995) Whole-genome random sequencing and assembly of Haemophilus influenzae Rd. Science 269: 496-512

13. Frosst P, Blom HJ, Milos R, Goyette P, Sheppard CA, Matthews RG, Boers GHJ, den Heijer M, Kluijtmans LAJ, Heuvel LP van den, Rozen R (1995) Identification of a candidate genetic risk factor for vascular disease: a common mutation in the methylenetetrahydrofolate reductase gene. Nat Genet 10: 111-113

14. Fujii K, Huennekens FM (1974) Activation of methionine synthetase by a reduced triphosphopyridine nucleotide-dependent flavoprotein system. J Biol Chem 249: 6745-6753

15. Garrow TA (1996) Purification, kinetic properties, and cDNA cloning of mammalian betaine: homocysteine methyltransferase. J Biol Chem 271: 22831-22838

16. Goyette P, Sumner JS, Milos R, Duncan AMV, Rosenblatt DS, Matthews RG, Rozen R (1994) Human methylenetetrahydrofolate reductase: isolation of cDNA, mapping and mutation identification. Nat Genet 7: 195-200

17. Goyette P, Frosst P, Rosenblatt DS, Rozen R (1995) Seven novel mutations in the methylenetetrahydrofolate reductase gene and genotype/phenotype correlations in severe methylenetetrahydrofolate reductase deficiency. Am J Hum Genet 56: 1052-1059

18. Gulati S, Baker P, Fowler B, Li Y, Kru W, Brody LC, Banerjee R (1996) Defects in human methionine synthase in cblG patients. Human Mol Genet 5: 1859-1866

19. Jacques PF, Bostom AG, Williams RR, Ellison RC, Eckfeldt JH, Rosenberg IH, Selhub J, Rozen R (1976) Relation between folate status, a common mutation in methylenetetrahydrofolate reductase, and plasma homoycsteine concentrations. Circulation 93: 7-9

20. Kaneko T, Tanaka A, Sato S, Kotani H, Sazuka T, Miyajima N, Sugiura M, Tabata S (1995) Sequence analysis of the genome of unicellular cyanobacterium Synechocystis species strain PCC6803 I. Sequence features in the $1 \mathrm{Mb}$ region from map positions $64 \%$ to $92 \%$ of the genome. GenBank accession \# D64002

21. Kang S-S, Wong PWK, Zhou J, Sora J, Lessick M, Ruggie N, Grcevich G (1988) Thermolabile methylenetetrahydrofolate reductase in patients with coronary artery disease. Metabolism 37: 611-613

22. Kang S-S, Wong PWK, Susmano A, Sora J, Norusis M, Ruggie N (1991) Thermolabile methylenetetrahydrofolate reductase: an inherited risk factor for coronary artery disease. Am J Hum Genet 48: 536-545

23. Katzen HM, Buchanan JM (1965) Enzymatic synthesis of the methyl group of methionine. VIII. Repression-derepression, purification, and properties of 5,10-methylenetetrahydrofolate reductase from Escherichia coli. J Biol Chem 240: 825-835

24. Kutzbach C, Stokstad ELR (1971) Mammalian methylenetetrahydrofolate reductase: partial purification, properties, and inhibition by Sadenosylmethionine. Biochim Biophys Acta 250: 459-477

25. Leclerc D, Campeau E, Goyette P, Adjalla CE, Christensen B, Ross M, Eydoux P, Rosenblatt DS, Rozen R, Gravel RA (1996) Human methionine synthase: cDNA cloning and identification of mutations in patients of the cblG complementation groups of folate/cobalamin disorders. Hum Molec Genet 5: 1867-1874

26. Li YN, Gulati S, Baker PJ, Brody LC, Banerjee R, Kruger WD (1996) Cloning, mapping, and RNA analysis of the human methionine synthase gene. Hum Mol Genet 5: 1851-1858

27. Mangum JH, Scrimgeour KG (1962) Cofactor requirements and intermediates in methionine biosynthesis. Fed Proc 21: 242 
28. Margaglione M, Mazzola G, Di Minno G, Andria G (1996) Elevated total plasma homocysteine and $677 \mathrm{C} \rightarrow \mathrm{T}$ mutation of the 5,10 -methylenetetrahydrofolate reductase gene in thrombotic vascular disease. Am J Hum Genet 59: 262-264

29. Matthews RG (1984) Methionine biosynthesis. In: Blakley RL, Benkovic SJ (eds) Folates and Pterins. John Wiley and Sons, New York, pp 497-553

30. Matthews RG, Vanoni MA, Hainfeld JF, Wall J (1984) Methylenetetrahydrofolate reductase: Evidence for spatially distinct subunit domains obtained by scanning transmission electron microscopy and limited proteolysis. J Biol Chem 259: 11 647-11650

31. Mudd SH, Uhlendorf BW, Freeman JM, Finkelstein JD, Shih VE (1972) Homocystinuria associated with decreased methylenetetrahydrofolate reductase activity. Biochem Biophys Res Commun 46:905-912

32. Old IG, Hunter MG, Wilson DTR, Knight SM, Weatherston CA, Glass RE (1988) Cloning and characterization of the genes for the two homocysteine transmethylases of Escherichia coli. Mol Gen Genet 211: 78-87

33. Old IG, Margarita D, Glass RE, Saint Girons I (1990) Nucleotide sequence of the metH gene of Escherichia coli $\mathrm{K}-12$ and comparison with that of Salmonella typhimurium LT2. Gene 87: 15-21

34. Roberts DL, Zhao S, Doukov T, Ragsdale SW (1994) The reductive acetyl-CoA pathway: sequence and heterologous expression of active $\mathrm{CH}_{3}-\mathrm{H}_{4}$ folate: corrinoid/iron sulfur protein methyltransferase from Clostridium thermoaceticum. J Bacteriol 176: 6127-6130

35. Rosenblatt DS (1995) Inherited disorders of folate transport and metabolism. In: Scriver CR, Beaudet AL, Sly WS, Valle D (eds) The metabolic bases of inherited disease. McGraw-Hill, New York, pp $3111-3128$
36. Smith DR (1994) Mycobacterium leprae cosmid B2126. Genbank Accession \# U00017

37. Steegers-Theunissen RPM, Boers GHJ, Trijbels FJM, Eskes TKAB (1991) Neural-tube defects and derangement of homocysteine metabolism. N Eng1 J Med 324: 199-200

38. Sumner J, Jencks DA, Khani S, Matthews RG (1986) Photoaffinity labeling of methylenetetrahydrofolate reductase with 8-azidoadenosylmethionine. J Biol Chem 261: 7697-7700

39. Swinburne J (1994) $2.2 \mathrm{Mb}$ of contiguous nucleotide sequence from chromosome III of C. elegans. Nature 368: 32-38

40. Put NMJ van der, Steegers-Theunissen RPM, Frosst P, Trijbels FJM, Eskes TKAB, Heuvel LP van den, Mariman ECM, Heyer M den, Rozen R, Blom HJ (1995) Mutated methlenetetrahydrofolate reductase as a risk factor for spina bifida. Lancet 346: 1070-1071

41. Watkins D, Rosenblatt DS (1988) Genetic heterogeneity among patients with methylcobalamin deficiency. Definition of two complementation groups, cblE and cblG. J Clin Invest 81: 1690-1694

42. Whitehead AS, Gallagher P, Mills JL, Kirke PN, Burke H, Molloy AM, Wier DG, Shields DC, Scott JM (1995) A genetic defect in 5,10-methylenetetrahydrofolate reductase in neural tube defects. Q J Med 88: 763-766

43. Wilcken DEL, Wilcken B (1976) The pathogenesis of coronary artery disease. A possible role for methionine metabolism J Clin Invest 57: 211-215 